\title{
Once upon a time in New Zealand
}

\author{
Library aspirations and colonial reality in the early years of European \\ settlement, or, 'The tone and character to civilization'
}

\section{J.E. TRAUE}

Public libraries, (as distinct from the private library of an individual with access dependent wholly on the favour of the owner) in the sense that books were available either to the members of a defined group, or to all those prepared to pay an entrance fee or subscription, or to everyone according to the rules of the institution, were part and parcel of New Zealand's foundation as a colonial outpost of European civilization in 1840. Our foundation 'public' libraries were in place by 1842 in Wellington, Nelson, and Auckland (there was a hiatus of some six years in New Plymouth), and appeared within a year of the settlements in Canter-

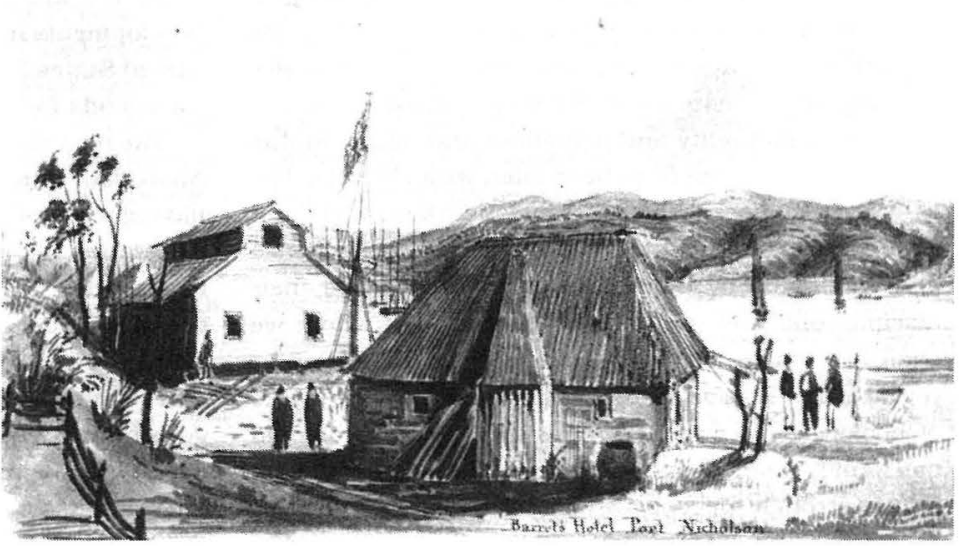
bury and Otago later in the decade.

This close relationship between our colonial settlement and libraries, not just a matter of chronology but of their very conception though not unique, was unusual. In the seventeenth-century British colonies in North America, and the eighteenth-century settlements in Australia, there was no necessary connection between settlement and libraries. There were considerable time lags before their first 'public' libraries appeared. It took 31 years from the founding of Jamestown in 1607 to the creation of the first American colonial public library in 1638', and then it was that of Harvard College, an institution of higher learning. In Australia it took 38 years from the arrival of the first fleet in 1788 to the foundation of the first 'public' library in Sydney. There was talk of a public library and many other similar edifices' in 1791, an appeal by Samuel Marsden for donations of money, books or tracts for the poor settlers, the soldiers and the convicts in 1809, and a proposal by Governor Macquarie in 1813, but it was not until 1826 that the Australian Subscription Library and Reading Room, a proprietary subscription library, was opened in Sydney. ${ }^{2}$

But it is significant that at least one group of settlers in the early seventeenth century, a community of Puritans departing from the Isle of Wight for Salem in 1629 to create their ideal society, had a Massachusetts Bay

The raupo whare which housed New Zealand's first public library, at the foot of Charlotte (Molesworth) Street, Wellington; Barrett's Hotel (second site) to the left, and the harbour just across 'the beach' (Lambton Quay). Original painting by Captain Owen Stanley, H.M.S. Britomart, 1840, owned by the Royal Society of Tasmania, Tasmanian Museum and Art Gallery.

Company Library on board, a collection of religious books for the settlers in the new community and for the conversion of the Indians. ${ }^{3}$ The library disappears from the historical record thereafter, but its existence and its purpose provides the first clue to our New Zealand experience. Some other very general clues can be found in changes in the English-speaking world since the seventeenth century, and in particular in the changes in attitudes to libraries in the early nineteenth century in Britain and the United States.

The new industrial society, gaining strength from the late eighteenth century, required a more highly educated workforce. The agricultural labourers who could function quite well with little more than the ability to sign their names, were now recruited to the factories of the industrial towns and cities, and needed a higher standard of literacy to function as members of a complex society more dependent on written information. Schools, cheap books, newspapers and periodicals, and public 
reading rooms and lending libraries, were seen as the appropriate instruments to educate this new workforce.

As well as this need for functional literacy for the new industrial workers it was argued by some that reading skills were necessary for them as citizens, as against those who objected to this on the grounds that indiscriminate and unnecessary education would radicalise the working class, would lead them to absorb the pernicious ideas of the Tom Paines of this world (sellers of Tom Paine's Rights of Man were being prosecuted and transported to Botany Bay), and bring disaffection and revolution. Useful knowledge, the reformers maintained. would be a bulwark against irreligion and combat the spread of objectionable political notions. It would give working men a taste for rational enjoyment as well as habits of punctuality and politeness and might, in due course, render them fit to be trusted with the vote. The Utilitarians, among them Jeremy Bentham and Lord Brougham (he is honoured in Wellington, New Plymouth and Wellington by their Brougham Streets) and their disciple, one Edward Gibbon Wakefield, of whom we shall hear more later, stood for popular education, a repeal of the taxes on knowledge to bring down the prices of books and newspapers. The Utilitarians promoted mechanics' institutes, self help, and libraries. Brougham argued strongly for cooperative book clubs, study circles and conversational associations for working men, and in order to reduce book prices, advocated measures such as narrower margins, more print on the page, and publication in cheap, affordable instalments.

They waxed lyrical about the power of the printing press, 'a Multiplication Table as applicable to the mind of man'4 which would transform minds by the dissemination of useful knowledge in the same way that steam power was transforming the outward face of English life. Ebenezer Elliott expressed their sentiments thus in verse:

Mind, Mind alone,

Is light, and hope, and life, and power!

Earth's deepest night, from this bless'd hour.

The night of minds, is gone!

"The Press!" all lands shall sing;

The Press, the Press, we bring.

All lands to bless:

Oh, pallid want! oh labour stark!

Behold, we bring the second ark!

The Press! The Press! The Press! ${ }^{5}$

There are no lyrical utterances about the power of public libraries which can quite match Carlyle and Elliott, but there are an increasing number of panegyrics on the benefits of free public lending libraries towards the mid-century and the enactment of the Public Libraries Act of 1850 in Britain and the growth of free libraries in the United States. By the early nineteenth century
William Lane had a British national network of commercial circulating libraries, and by 1821 there were some 500 flourishing proprietary libraries and 6,500 local cooperative book societies and clubs for the middle classes. Between 1817 and 1830 Samuel Brown's itinerating libraries (which provided a model for Tasmania, the Otago Provincial Council, and are the ancestors of the Country Library Service's book boxes) had expanded to about 50 village sites in East Lothian; by 1850 there were over 700 mechanics' institutes in Britain, each with its library, a bookstock of some 700,000 volumes and a circulation of 1,820,000 a year. Similar developments took place on the eastern seaboard of the United States. ${ }^{6}$ Publicly available libraries were high on the agenda for the rational reform of society.

The next clue is provided by the settlement in South Australia, unique among the Australian colonies in having a fully-formed library ready for public use at its foundation in 1836. There was not just a chronological coincidence; there was a conscious plan and a philosophical underpinning. In 1831 the National Colonisation Society's earliest plans for South Australia included a circulating library to help educate the colonists for selfgovernment. Within two months of the empowering act, the South Australia Act of 1834, the South Australian Literary Association was formed in London to promote the cultivation and diffusion of useful knowledge throughout the colony and a library of reference and circulation was one of the five means proposed to achieve that end. A collection of 78 books and four bound volumes of pamphlets was donated by Robert Gouger, supplemented by other gifts from George Fife Angas and the Society for the Diffusion of Useful Knowledge. This made up approximately two hundred volumes, the foundation collection, which went out to South Australia in a stout iron box on the Tam O'Shanter in 1836. Once in Adelaide it went into storage, undisturbed for two years by the colonists thirsting for useful knowledge, until it became part of the collection of the mechanics' institute founded in $1838 .^{7}$ The gap that had opened up between London aspirations and colonial reality is an omen of later developments in New Zealand.

The philosophical underpinnings for the aspirations of the new colonists are apparent in Richard Davies Hanson's inaugural address to the South Australian Literary Association in London. There are two major themes; the need to fill the intellectual wants of the settlers to prevent a 'retrogade' step in civilization, and the role of useful knowledge in harmonizing the interests of the labouring classes and the capitalists. 'With an instructed people we may hope to found a reasonable community'. ${ }^{8}$ The source of his ideas is Edward Gibbon Wakefield, the father of 'scientific' colonization. Wakefield had argued in a stream of books and pamphlets the folly 
of founding colonies in order to export Britain's problems and the wisdom of scientific colonization, based on the experience of the Greek communities around the Mediterranean in the ancient world where successful replicas of the parent society and culture were formed, which would create opportunities for the mother country. His views on the need to keep land prices high in new colonies are well enough known to New Zealanders. The 'sufficient price' for land would cure the problem endemic in colonial societies in the Americas and Australia of a shortage of labour which stunted their economic growth. It would also solve the endemic colonial social problem; the lack of leisure time and the consequent degeneration of civilized life. In Letter from Sydney his views on the decline of refined existence in colonies are expressed in uncompromising form.'... did I not mention something about intellectual society? There is no such thing in this country... We are not barbarians - the colony is too young for that... [but] Some generations hence, their descendants will probably be as uncouth, and ignorant, and violent as the great mass of North Americans... Perhaps ... they may become as wild as the inhabitants of the Pampas, or as gross, lethargic and stupid as the Boers of the Cape of Good Hope... Literary men, men of science, philosophers do not emigrate to new countries where their acquirements would be neither rewarded nor admired. ... the great mass of emigrants from England ... came here to live, not to enjoy; to eat and drink, not to refine; to "settle" - that is, to roll in a gross plenty for the body, but to starve their minds. ... we are in a barbarous condition, like that of every people scattered over a territory immense in proportion to their numbers; every man is obliged to occupy himself with questions of daily bread; there is neither leisure nor reward for the investigation of abstract truth: moneygetting is the universal object; taste, science, morals, manners, abstract politics, are subjects of little interest, unless they happen to bear upon the wool question; and, what is more deplorable, we have not any prospect of a change for the better.... [such colonists] make no progress in the art of living; [they] in respect to wealth, knowledge. skill, taste, and whatever belongs to civilization, have degenerated from their ancestors ... a people who have become rotten before they are ripe'. ${ }^{9}$

The colony in South Australia and the settlements in New Zealand proposed by Wakefield's disciples were to be founded on strictly rational principles, with a sufficient price for land, and a fund to sponsor migrant labour. They were to have from the beginning the infrastructures necessary to support civilized living, and that meant books and libraries. Libraries were to provide the tone and character to civilisation in these model societies.

A two-page folder dated 8 July 1839 published in
London and headed 'First Colony of New-Zealand' ${ }^{10}$ outlines the plan. A Literary, Scientific, and Philanthrophic Institution for the benefit of the British Settlers and Native Inhabitants of the Islands of New Zealand had been formed under the designation 'The First Colony'. This consisted of the heads of families and others about to settle in New Zealand on lands purchased by the New Zealand Company, 'impressed with the belief that a colony to be prosperous should be composed of a portion of an old Society, transferred complete in all its parts, and containing at least the rudiments of all the institutions which give the tone and character to civilization'. The pamphlet laments that there was not enough time to set up distinct societies for each institution and the "First Colony' had therefore been established as an umbrella organisation of trustees 'for the administration of any funds which may be contributed for scientific or philanthropic purposes'. It further noted that separate plans were in hand for a church" and funds were being received for an 'Infant School and Orphan Asylum for the native children'. The committee drew attention to two needs, 'the formation of a Public Library, with a General Museum and Scientific Institution, and the establishment of a Dispensary, or Hospital, for the benefit of the settlers, and the Aborigines of the country.... It is obvious that without the former of these Institutions, a high standard of civilization cannot be maintained, and that it is beyond the power of the individual settlers to provide for it.... It is believed that Governments and public societies, by communicating their official papers and transactions, and noblemen and gentlemen, by giving duplicates of works, will, without inconvenience to themselves, confer an inestimable boon on the colony by their joint contributions. Subscriptions in money will be received also, but it is imagined that there are few individuals acquainted with the subject who will not cheerfully present at least one volume, or one specimen of science or art, to be deposited, as a token of their good will, in the Public Library of the New-Zealand Colony.... The contributions most valued will be Books, whether in ancient or modern languages, Manuscripts, Maps, Charts, Engravings, Paintings, and Sculptures, with copies or casts, Models of Inventions and of Buildings, specimens of Minerals and of Natural History, Coins, Medals, \&c, and whatever may suggest itself as essential to the plans of a Colony which proposes to cherish the refinements of civilization from the beginning of its existence'.

The Directors of the New Zealand Company were sympathetic to the creation of these institutions and made a grant towards the endowment of the church, but appear not to have allocated funds for the Public Library of the First Colony, that is Wellington, though they did make contributions in Nelson and New Plymouth. In line with the provisions for the South Australia settlement. 
they provided for reading classes on the emigrant ships and established libraries for educational and leisure reading during the outward voyage, with the intention that these books should then become part of the stock of the settlements' public libraries. 'Aid-in-kind' was not an invention of the Otago Provincial Council in the 1860 s or of the Country Library Service in the 1930s, it was there at our colonial foundation.

A letter to Colonel William Wakefield, dated 16 November 1839, records a Bill of Lading for sundry cases of books shipped on the Bolton, 'some for the New Zealand Library and others for the disposal of the Revd. Mr Churton'. ${ }^{12}$ The documentation for the voyage of the Slains Castle to Wellington in 1840 contains a list of books 'for the use of the Emigrants to be handed over to the Company's Principal Agent on arrival in New Zealand' and a list of the same books appears for the voyage of the Lady Nugent. ${ }^{13}$ A similar core collection, with additional material (there were many more books about New Zealand) and with higher rates of duplication, is listed for the Olympus in $1842^{14}$, but the 'library' on the Amelia Thompson sent out to New Plymouth in $1841^{15}$ differs markedly from the standard selections shipped to the New Zealand Company settlements in Wellington and Nelson. Other such lists exist in the Company's records for the Sir Charles Forbes, George Fyfe, Bombay, Indus and Blenheim in 1842. ${ }^{16}$

From the surviving evidence it appears that a core collection of some sixteen titles, the majority intended to support elementary education, heavily duplicated (duplication rates vary betweeen 24 and 3) was provided for use on the emigrant ships of the New Zealand Company as a matter of Company policy, and on arrival in New Zealand these books were to be surrendered to the Company's agent for the local library or libraries. The very heavy duplication involved, and the emphasis on texts for elementary reading, made the bulk of these libraries more suitable for the new schools of the colony than the public library, and in Nelson that appears to have been their fate: 'The books sent out in the Company's vessels for the use of the Emigrants on board, have been distributed amongst the different schools of the Settlement, and are generally approved and very serviceable'. ${ }^{17}$

Another element of the New Zealand Company's policy on libraries can be inferred from the plan for the town of Wellington drawn up in London by Samuel Cobham. Locations are shown for markets, public baths, hospitals, prisons, schools, a mechanics' institute, a museum, a public record office and a public library. But the New Zealand Company appears not to have been as interventionist as the promoters of the South Australian colony who originally proposed to establish the institutional infrastructure of the new colony and then to let the colonists gradually take it over and provide the financial support themselves, on the grounds that the colony would initially be too weak to provide such services unaided. The 1831 plan of the National Colonisation Society provided for the Company to supply teachers for instructing children, and adults in colonial agriculture, and a circulating library. ${ }^{18}$

In the first New Zealand Company colony in Wellington the books, those gathered through donations by the First Colony of New Zealand Society using the offices of the Company in London, and the libraries supplied by the Company for the emigrant ships and consigned to their principal agent in Wellington, were given as aid-inkind, but the colonists had to provide the institution, that is the building, the staff and the management. A meeting of settlers was held on 1 December 1840 in Barrett's Hotel, followed by several more, and by early 1841 a librarian was installed at $£ 75$ a year: a raupo whare was purchased for $£ 30$ to house the newly formed Port Nicholson Exchange and General Library and the stock of books was handed over. In April 1842, a year after its opening, the Public Library and Reading Room was wound up and its stock of books, some 160 titles, transferred to the new Mechanics' Institute, Public School and Library, which was formed on 2 May 1842 and opened on 1 June. ${ }^{19}$

The Committee of the Mechanics' Institute was soon soliciting financial assistance from the Court of Directors of the Company. In a letter dated 28 January 1843 , they respectfully called to their attention the efforts they have been making to diffuse useful knowledge among the Settlers in your first Colony' and reminding the directors of their warm sentiments, frequently expressed, on the desirableness of such institutions and their benefits. They attached the first half yearly report, and details of their memorial to the Governor requesting that $£ 40$ set aside for education in the Estimates be allocated to the Institute and also a suitable site for a building. ${ }^{20}$ Sufficient assistance was not forthcoming, either from the authorities or the members, and the institute packed away its library and went into abeyance in 1844 , to be revived in 1849 as the Athenaeum and Mechanics' Institute. Self-help, that pillar of Utilitarianism, in a poor, thinly settled colony was insufficient to guarantee those institutions necessary to provide the tone and character of civilization.

The Nelson settlement required even more self-help. There was no Second Colony Society in London gathering a library before the colonists set sail. On the voyage out on the Whitby the Nelson Literary and Scientific Institution was formed on 17 May 1841 for the objects of diffusing general knowledge (by means of an extensive library), and encouraging any scientific researches.' 21 The cabin passengers subscribed $£ 20$ for the purchase 
of books, gentlemen on board donated some 700 volumes, and at Teneriffe, where the Whitby and Will Watch met, the money was sent back to the Company's offices in London to purchase suitable reference books. On 25 August a circular issued from the Colonists' Room at the Company's offices in London outlined the events on the Whitby and appealed for more donations in words reminiscent of the appeal of the First Colony Society in 1839. In September 1841 the Court of Directors of the New Zealand Company made a grant of 1100 to the new Institute. A meeting was held in Nelson on 27 May 1842 and the library building was opened on 27 September with a stock of about 500 volumes. ${ }^{22}$ By 1844 a member estimated the library to contain 'one or two thousand titles' ${ }^{23}$ In early 1855 the Nelson Provincial Council voted $£ 100$ to the Nelson Institute, and soon thereafter $£ 150$ for distribution to country libraries and $£ 200$ to subsidise reading rooms in country districts. By 1860 there were 14 rural libraries receiving government aid. This intervention of Provincial government to support libraries is significant. It was a path down which New South Wales and Victoria had already started, and South Australia went in 1856 after a government inquiry into the failure of the South Australian Institute and Subscription Library. The lesson that the colonists in South Australia had learned was that their prized principles of voluntarism and enlightenment through education were not compatible with their colonial environment, and that an element of state aid was essential. ${ }^{24}$

New Zealand's most successful experiment with state help for libraries was in Otago. The Otago Association in 1847 was advocating the setting aside of revenue from land sales to support churches, schools and to purchase a library. In September 1848 the Blondell arrived with a consignment of books, and two catalogues. In 1849 the library building was erected, and on 23 June 1849 the Library of the Church of Otago opened with the stock brought out on the Blondell and the Philip Lang. Plans were formulated immediately for an Otago-wide library service. On 31 August 1849 William Cargill, the Resident Agent for the New Zealand Company, wrote to William Fox: "with reference to the catalogue and rules of our infant library, No. 16 of the statistics, it is our purpose when more matured to adopt the plan of Mrs Brown of Haddington by having boxes prepared to hold fifty selected vols. each. The box is made to stand on end, as a small library, and is furnished inside with shelving, pen and ink, printed copies of its own catalogue, and a little book for the use of the Librarian. The people of any small district will then be entitled to elect among themselves their own librarian, and on being approved to have one of these boxes at a time. subject to the same rules and rates of subscription as the parent library. These boxes being numbered, and their printed catalogues shewing a different set of books in each of them, the applicants can choose for themselves ... ${ }^{25}$ The 1861 catalogue of the Church of Otago lists 1600 volumes, and the library of the Dunedin Athenaeum and Mechanics' Institute opened in 1862 with some 350 titles. In 1862 a provincial system of libraries was inaugurated under the control of the Otago Education Board, which distributed collections of books, centrally purchased and uniformly bound, together with printed catalogues, to the smaller circulating libraries, and provided a mixture of aid to the Athenaeums and Mechanics' Institutes throughout the province. By 1875 there were 88 public libraries receiving aid-inkind, for a population of $115,680,{ }^{26}$ and 113 libraries by 1877. Similar ventures in regional support, later and lesser, were adopted by Auckland, Canterbury, Hawkes Bay and Wellington, and the Westland County Council. ${ }^{27}$

With the abolition of the provinces in 1876 there ended New Zealand's first successful experiment in making available state aid to match local voluntarism. The legislation of the central government: the Public Libraries Act of 1869 - modelled on the British act of 1850 - which empowered local authorities to establish free public libraries, but provided no incentives and had next to no takers until the 1880 s, and the much more important Public Libraries Subsidies Act of 1877 which permitted central government to continue subsidies to local libraries, was erratic and ineffectual compared with the earlier provincial subsidies and aid-in-kind.

Such central government subsidy was unusual enough to be noticed by C.W. Holgate, ${ }^{28}$ an English librarian who visited both Australia and New Zealand in 1884 and published two detailed accounts of his findings in 1886. Holgate, accustomed to the wholly local provision for public libraries common in Britain and reinforced by the Public Libraries Act of 1850 , noted the level of government funding for the public libraries in the major cities of Australia, and was astonished by the wholly government-run Sydney Free Public Library. He considered that 'on the whole, I think the advantages of being looked after by a paternal government are outweighed by the disadvantages'. He did admit, however, to 'wonder and surprise' to discover in Victoria such 'large and wellmanaged libraries in a country whose history goes back but thirty-three years'. ${ }^{29}$ Holgate in 1884 had observed in Australia one manifestation of what came soon to be known as Australasian state socialism and the object of admiration of investigators from Britain, France and the United States by the turn of the century.

In both South Australia and the Wakefield-inspired colonies in New Zealand, those model societies on rational principles in the southern Pacific, a gap quickly opened up within the first years of settlement between the aspirations and the harsh colonial reality. The Company itself was never wealthy enough, nor were there 
enough capitalists in residence, to endow and subsidise the institutional infrastructure that the theory held to be necessary to provide the tone and character to civilization. There was not enough capital and cheap labour to recreate the structured society sought by Wakefield, and all the settlements lacked the concentrations of population essential to support urban institutions. In such societies self-help alone would not and could not provide. The feared retrograde step in civilization endemic in other modern colonies was, it seemed, to be their lot in societies of small isolated villages spread over large areas, in resource-poor, predominantly subsistence agricultural and large-scale, low cost, pastoral economies.

But the desire of the settlers, not just those in the model Wakefield colonies with their high initial aspirations, but also those in the penal colonies in New South Wales, Tasmania, and Western Australia, and the freesettler colony in Victoria, for the amenities of civilized life, especially libraries, was remarkably resilient. They carried a virulent infection from nineteenth-century Britain in their trunks of books and it was not to be subdued by distance, salt water, or the shock of immersion in colonial life. After only some two decades of experiment and failure they opted to supplement selfhelp with state aid in the provision of libraries; to use the ballot-box to allocate the community's resources rather than relying on the then standard economic mechanisms, the ability to pay supplemented by charity, to ensure their rights to books.

I wish to acknowledge the work of my students in Resources for New Zealand Studies in 1991 in compiling lists of references, especially the work of Megan Symes, Debbie Sidelinger, and Janine Delaney.

From a Stout Centre seminar on 7th October 1992

Jim Traue is an Honours graduate in English Literature from the University of Auckland. His whole professional life has been spent in libraries, in the National Library service, the General Assembly Library, DSIR, and Alexander Turnbull Library. He was Chief Librarian at the Alexander Turnbull Library from 1973 to 1990. He is now the Teaching Fellow in the Department of Library \& Information Studies at Victoria University of Wellington. His books include: New Zealand Studies: A Guide to Bibliographic Resources and Committed to Print.

\section{FOOTNOTES}

' Jesse H. Shera, Foundations of the Public Library (Chicago, 1949), 18

2 John Balnaves and Peter Biskup, Australian Libraries, 2nd ed. (London, 1975), 25

3 Jesse H. Shera, Foundations of the Public Library, 16-17

${ }^{4}$ Guoted from Carlyle's Republican, March 1, 1822, in William $\mathrm{H}$. Wickwar, The Struggle for the Freedom of the Press 18191832 (London, 1928), 214-15
5 'The Press', Poetical Works (London, 1844). I, 122

6 See Richard Altick, The English Common Reader (Chicago, 1957). and Sidney L. Jackson, Libraries and Librarianship in the West; a Brief History (New York, 1974)

7 Carl Bridge, A Trunk Full of Books; History of the State Library of South Australia and Its Forerunners (Adelaide, 1986)

8 Carl Bridge, 4-6

9 The Collected Works of Edward Gibbon Wakefield, edited with an introduction by M.F. Lloyd Prichard (Glasgow, 1968), $101-77$

10 Bagnall 1925

11 See Bagnall 1926

12 Public Record Office. Colonial Office, NZCo 102/1, 262-3

13 Public Record Office. Colonial Office, NZ Co 208/10, 45; 131

${ }^{14}$ National Archives. New Zealand Company, NZC 234/2. The document is undated, but letters in the same envelope are dated 1842. Sadie Foote, in her 'New Zealand Libraries: a Bibliography' (Library School bibliography, 1948) dates this at 1850.

${ }^{15}$ H.E. Carey, New Plymouth Public Library, a History 1848 1960 (New Plymouth, 1960), 3.

${ }^{16}$ Dulcie Gillespie-Needham, The Colonial and His Books (PhD Thesis in English, Victoria University, 1971), 231

${ }^{17}$ General Summary of the Nelson Settlement Taken in Last Week of October, 1843, Table 17, Education (copied from originals held in the New Zealand Company archives, National Archives NZC 3/14), Alexander Trunbull Library, qMS

${ }^{18}$ Douglas Pike, Paradise of Dissent (Melbourne, 1967), 59

19 Joan Stevens, Brother Fred and the Two Cultures: New Zealand's First Librarian', New Zealand Libraries, 31 (October 1968), 175-98; J.C Dakin. 'The Origins and Beginnings of continuing Education in Wellington', Continuing Education in New Zealand , 10 (May 1978),77-97

${ }^{20}$ National Archives. New Zealand Company, NZC $3 / 3$ no. 17

${ }^{20}$ Arthur Wakefield, Diary 1841-42, v.1, Alexander Turnbull Library, qMS

${ }^{21}$ J.C. Dakin, 'Adult Education and Social Class in Early Nelson 1841-61', Continuing Education in New Zealand, 12 no. 2 (October 1980), 22-43

${ }^{22}$ Samuel Stephens, Letters and Journals, v.2, 343-4. Alexander Turnbull Library, MS 1842-55

${ }^{23}$ Carl Bridge, A Trunk Full of Books.

${ }^{24}$ National Archives. New Zealand Company, NZC 3/31, Cargill to Fox, 31 April 1849 (no.42). Missing since 1982, but quoted by Sadie Foote. 'New Zealand Libraries: a Bibliography' (Library School bibliography, 1948) 3-4.

${ }^{25}$ John Harris, 'Otago Libraries 1848-1948', New Zealand Libraries , 11 (March 1948), 25-34

${ }^{26}$ C.W. Tolley, 'Library Legislation and Government Aid. Part I-The Provincial Period', New Zealand Libraries, 22 [October 1959), 169-78

${ }^{27}$ An Account of the Chief Libraries of New Zealand (London, 1886)

${ }^{28}$ An Account of the Chief Libraries of Australia and Tamania (London, 1886), 32, 26. 